\title{
REGIONAL DEVELOPMENT INSTRUMENTS FOR PROMOTION OF ENTREPRENEURSHIP IN TERRITORIES WITH UNFAVORABLE SOCIO-ECONOMIC SITUATION: THE CASE OF THE LATVIA
}

\begin{abstract}
Dace ZIEDINA, Faculty of Economics and Social Development, Latvia University of Agriculture; Jelgava, Svētes iela 18, LV-3001, Latvia, ziedina.dace@gmail.com (corresponding author)

Modrite PELSE, Faculty of Economics and Social Development, Latvia University of Agriculture; Jelgava, Svētes iela 18, LV3001, Latvia, modrite.pelse@1lu.lv

The development gap between regions and even countries has always been actual problem in field of regional policy. Regional development disparities especially are important problem in territories with unfavourable socio-economic situation. To minimize this problem, many Eastern Europe countries, including Latvia, implemented special economic zones and free ports as regional development instrument with aim to mitigate regional development differences between regions by attracting investments and creating new jobs.

Experience with special economic zones in Latvia are likely close with Poland's case, thus experts from Poland affirms that, every 100 jobs given in special economic zone create on average about 72 jobs outside the special economic zone hosting territory and 137 jobs in neighboring counties. Latvia, since the restoration of sovereignty, established five economic zones in total - two of them are situated in Latgale, which is the least developed region of Latvia. Researchers have not been widely contributed to analysis of special economic zones impact to regional development. Authors evaluated impact of created job places of special economic zones in Latgale region to unemployment level.

Results of research show that special economic zones as regional development instrument creates significant impact to regional development in territories with unfavourable socio-economic situation.
\end{abstract}

Keywords: economic policy tools, entrepreneurship, regional economic development, special economic zones.

\section{INTRODUCTION}

History of special economic zones in Latvia are longer than twenty years, but evolution of this instrument to regional development (research object) has not been done. There are some specific limitations to lack of such an evolution, firstly, empirical studies includes some particular, fragmental analysis of special economic zones impact to regional development. Secondly, till 2017, when new special economic zone in Latvia, Latgale region (Latgale special economic zone) was established, special economic zones was not considered as significant instrument for promotion of entrepreneurship.

In case of Latvia authors used forecasting method, based on facts and future based assumptions. Aim of this research is to evaluate impact of created job places in Latgale special economic zone. To accomplish aim, main tasks were set. First, to analyse regional development instruments used in national and local level; second, to develop methodology for assessing the impact of special economic zones.

\section{RESEARCH METHODOLOGY AND DISCUSSION}

In recent decades viewpoint about effective regional policy instruments and approach to foster development in territories, has changed in developed countries (Barca, 2012). The Organization for Economic Co-operation and Development has developed main characteristics of traditional and new regional policy. Traditional regional policy in agenda of developed countries policy makers appeared in the 20th century 50s-60s. Main object or center of regional policy was income, infrastructure and employment disparities between regions, wherewith main regional development instruments were transfer of financial instruments from developed to territories with unfavorable socio-economic situation and large scale public investments, especially for less developed regions. New regional policy, instead of resources redistribution, use approach which promotes to development of territories - by encouraging the competiveness of territories, based on the specific advantages of territories and unused potential for each territory. New regional policy is oriented not only to the less developed regions, but to the entire country - offering for each region necessary regional development instruments according to situation (OECD, 2010). Regional policy planners in national level use different 
instruments for promotion of entrepreneurship in territories with unfavorable socio-economic situation and theory based statement is clear that regional development should support sustainable socio-economic development by improving the living standards and decreasing unemployment, boosting economic activity and stimulating investment in the private and public sectors (Apostolache, 2014).

Regional Policy Guidelines 2013-2019 (Latvia) as mid-term national planning document, affirms that solutions which are chosen in the framework of regional policy should be adapted to good practice of designing and implementation of effective regional policy (Regional Policy..., 2013). Long term trends in the development of territories in Europe and specific situation in Latvia should be taken into account. Authors based on information above mentioned Regional Policy Guidelines 2013-2019 summarized instruments which are used for regional policy (see Fig.1).

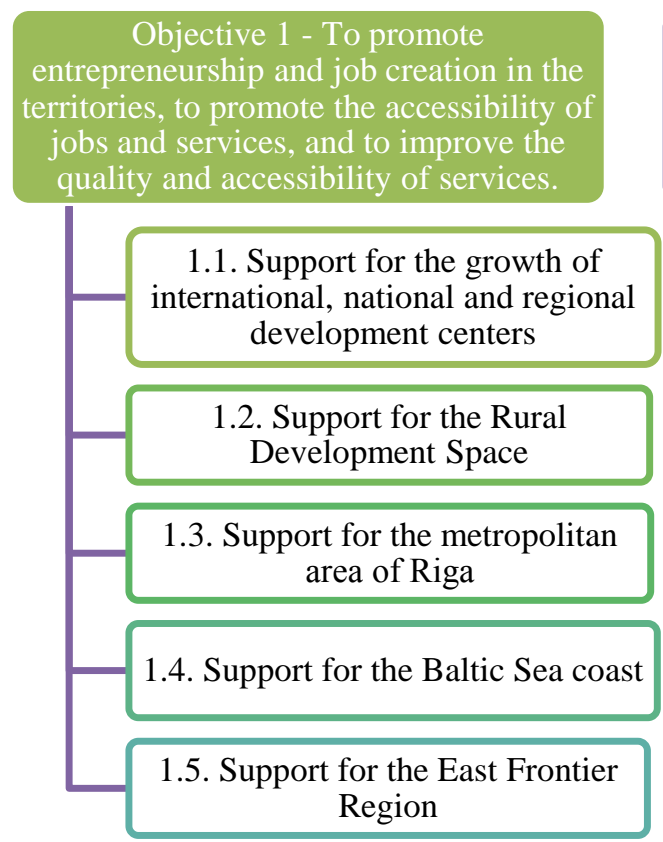

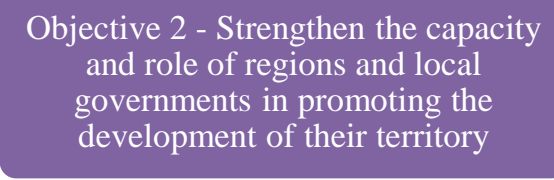

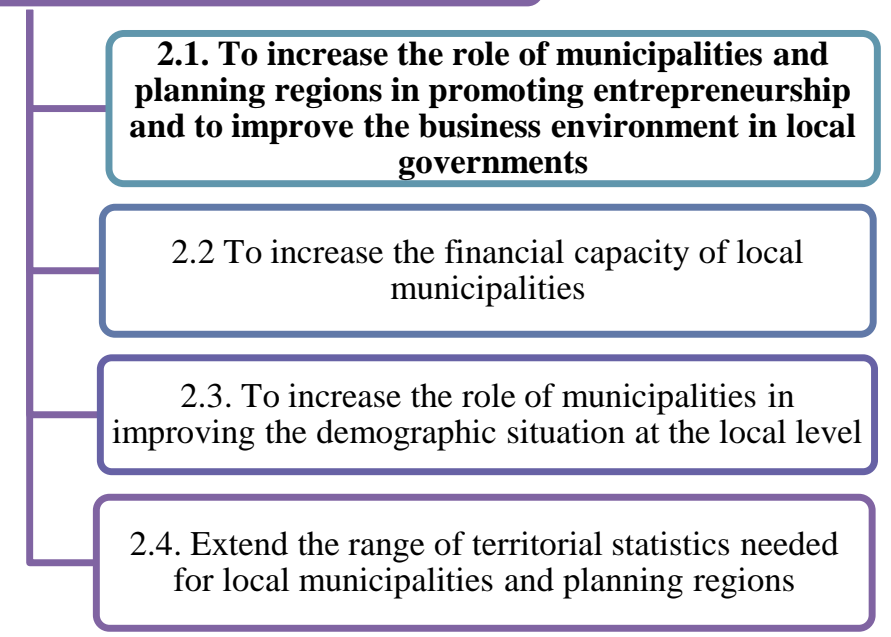

Source: authors' designed by information Ministry of Environmental Protection and Regional Development (Latvia)

Figure 1. Objectives of regional policy and instruments for their achievement, the case of the Latvia

According to information from Figure 1, such regional development instruments, for example, can be tax policy in general and reduced taxation in special economic zones; and other instruments which are regulated by European Union regulatory framework and national laws, etc. In case of Latvia, national level instruments for promotion entrepreneurship can be developed for some region individually within specific action plan.

In local level municipalities are main actor for promotion of entrepreneurship, therefore national laws should provide rights for municipalities to use such instruments according to their needs and possibilities. Good practice shows that instruments in local level are complementary to national level instruments.

Ministry of Environmental Protection and Regional Development (Latvia) has summarized main instruments for promotion of entrepreneurship; instruments are included within municipalities planning documents and are based in four main categories - administration, infrastructure, marketing activities and other specific instruments for realization of entrepreneurial activity (see Fig. 2).

According to Figure 2 in most cases municipalities can use instruments for promoting entrepreneurship without specific normative regulation in national level, but in some cases as local tax and fees relief, specific normative regulation in national level has to be established. As known, urban areas are wealthier than rural ones because of their higher productivity and their greater ability to attract companies and employees (OECD, 2011). In case of Latvia this statement is suitable; during research authors focused on special economic zones as one of the main regional development instrument. Special economic zones can play a catalytic role in economic development, provided the right business environment and policies are put in place (Asian Development Bank, 2015).

Basically special economic zones in Latvia were historically developed zones with narrow aim of promotion of entrepreneurship. However, experience of establishment of Latgale special economic zone is likely close with Poland's case, thus experts from Poland says that, every 100 jobs given in special economic zone create on average about 72 jobs outside the special economic zone hosting territory and 137 jobs in neighboring counties (Cizkowicz et al., 2015).

Special economic zones can make positive influence and effect to territories with negative socio-economic background, bet at the same time few empirical studies identify negative spillovers and still others find no spillovers at all (Cizkowicz et al., 2015). To evaluate special economic zones as regional development instrument, studies have used various methodologies ranging from descriptive case studies to careful economic evaluation, but findings are particularly hard to generalize because of variety of enterprise zones and local economic conditions (Bondonio et al., 2007). 

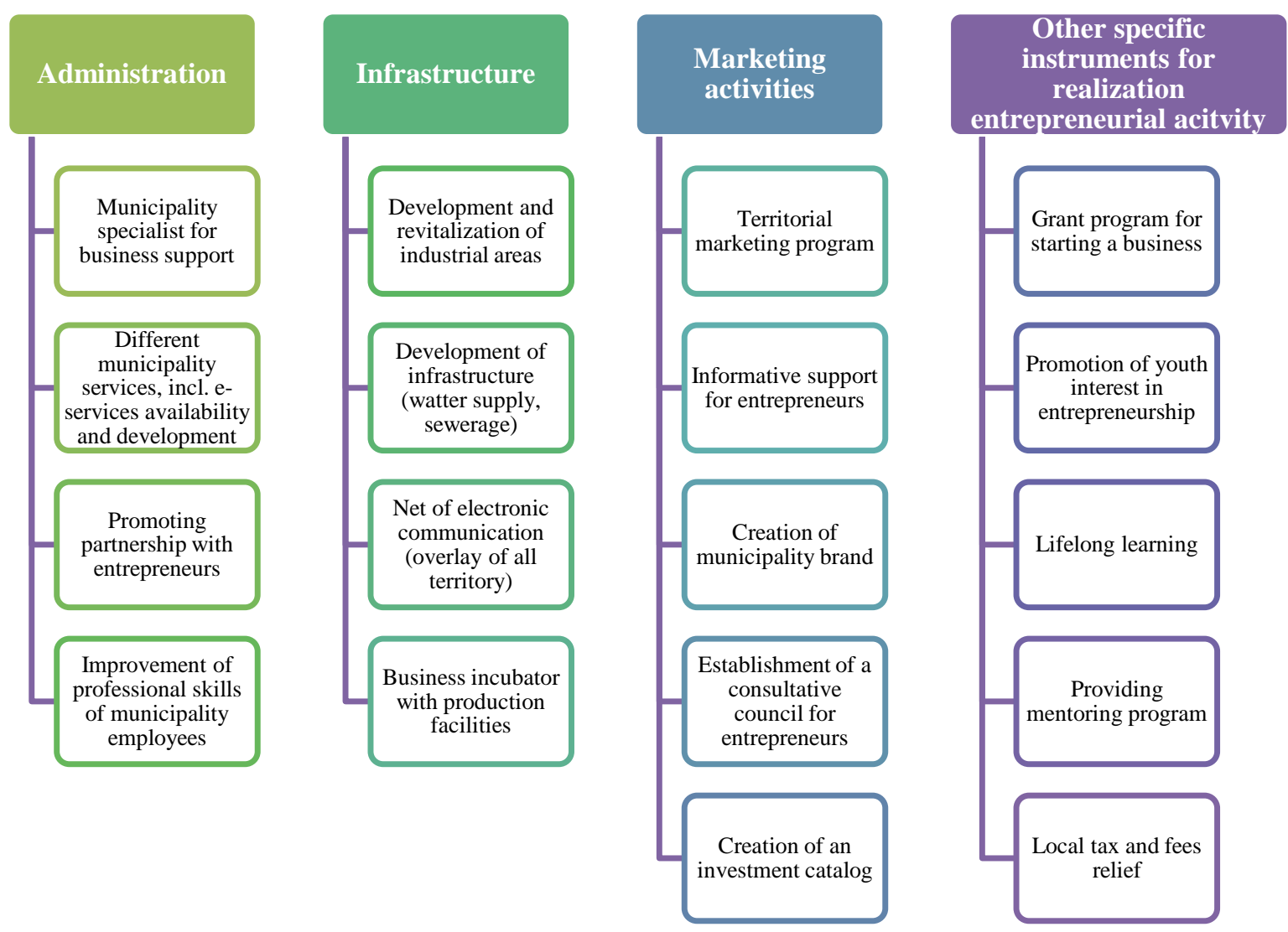

Source: Ministry of Environmental Protection and Regional Development (Latvia)

Figure 2. Main instruments for promotion of entrepreneurship in local level

Many economists define special economic zones, but no consensus has been achieved in the defining concept "special economic zone" (Hazakis, 2014; Farole et al., 2011). Regarding to different types of economic zones (for example - Freeport, investment zone, special economic zone, free trade zone, etc.) researchers and economists use general term "special economic zone" (Ziedina et al., 2017), according to that afore mentioned term is used further in this article.

Latvia, since the restoration of sovereignty, established five economic zones in total - two free ports with access to the sea (Freeport of Riga and Freeport of Ventspils), one special economic zone with access to the sea (Liepaja Special Economic Zone) and two special economic zones without access to the sea-Rezekne Special economic zone and Latgale special economic zone (Figure 3). Two of economic zones are situated in Latgale - least developed region of Latvia; however, other economic zones are situated in regions with relatively higher territory development index, especially in Riga. (Ziedina et al., 2017). According to data from Central Statistics Bureau of Latvia, gross domestic product (hereafter - GDP) in Latvia shows important indicator - in Latgale region GDP (at current prices) is 2,6 times lower than average GDP in Latvia (year 2014, GDP in Latvia - 11838 EUR, in Latgale region - 5981 EUR). Such difference between regions should be taken aware by using customized regional development instruments.

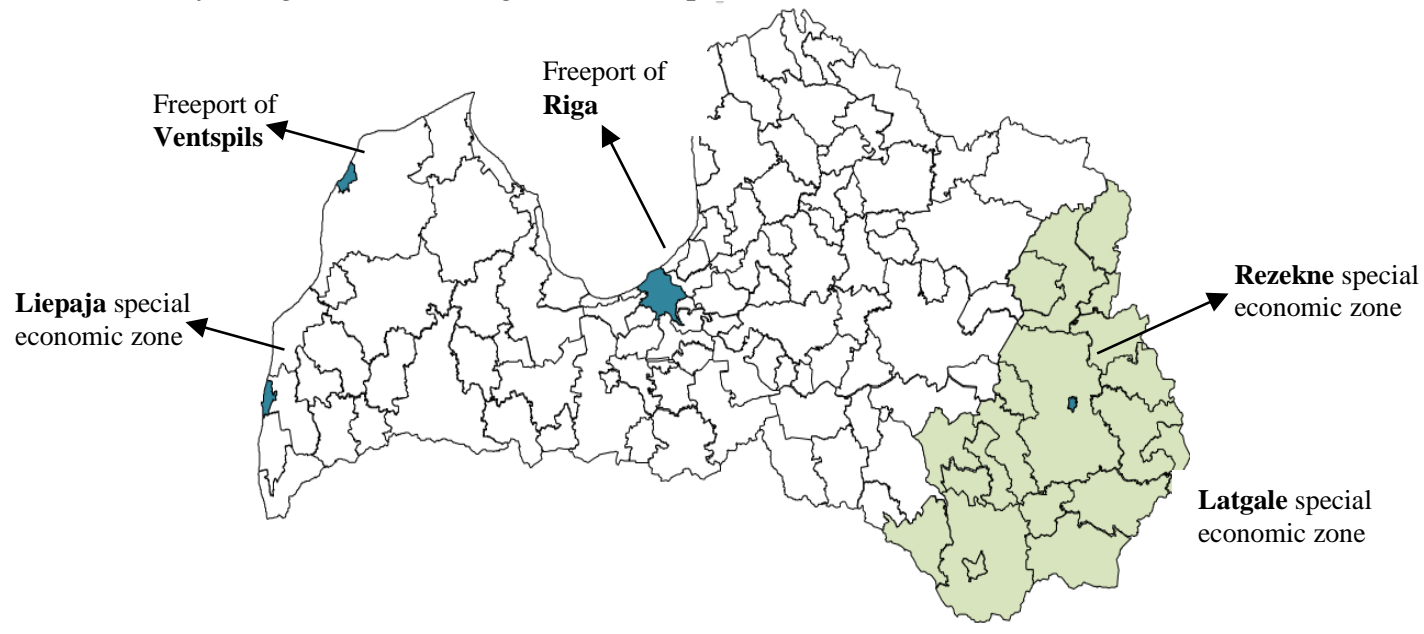

Figure 3. Location of economic zones in Latvia 
For each special economic zone particular laws are established and law "Application of Taxes in Free Ports and Special Economic Zones" (2001) is general for all five special economic zones.

The Free Port of Riga Law (2000) regulates action of freeport of Riga; this law determines the principles of operation and management procedures for the Free Port of Riga (hereinafter - the Free Port) in order to promote the participation of Latvia in international trade, attract investments, develop manufacturing and services, as well as create new jobs. Freeoprt of Riga is single-municipality territory, established in 1990.

The Free Port of Ventspils Law (1997) regulates action of freeport of Ventspils; this law determines the principles of operation and management procedures for the Free Port of Ventspils (hereinafter - the Free Port) in order to promote the participation of Latvia in international trade, attract investments, develop manufacturing and services, as well as create new jobs. Freeoprt of Ventspils is single-municipality territory, established in 1997.

Law on Liepaja special economic zone (1997) regulates action of Liepaja special economic zone; this law prescribes the procedures for the management and use of the Liepāja Special Economic Zone, and also peculiarities for performance of commercial activity and investments, activity with immovable property and work peculiarities of foreigners in the Liepāja Special Economic Zone. Liepaja special economic zone is single-municipality territory, established in 1997.

Law on Rezekne Special Economic Zone (1997) regulates action of Rezekne special economic zone; this special economic zone was established with the aim of promoting trade, developing industry and traffic, as well as goods export and import through Latvia. Task of Rezekne special economic zone is to attract investment for the development of production and infrastructure and the creation of new jobs. Rezekne special economic zone is two municipality territory, established in 1997.

Law on Latgale Special Economic Zone (2016) regulates action of Latgale special economic zone; Latgale special economic zone is established with the aim to facilitate the development of the Latgale region by attracting investment for the development of manufacturing and infrastructure and creation of new jobs. Latgale special economic zone opposite to other Latvias special economic zones is multi-municipalities territory, established in 2017.

\section{RESEARCH RESULTS}

There is no scientifically approved methodology for assessing the impact of special economic zones; besides only in rare cases specific indicators (example - new job places) are identified for special economic zones.

Researchers declare that evaluations of economic zones should carefully compare outcomes in a control group and other places that are similar, but did not receive economic zone benefits (Bondonio et al., 2007). Such experiment cannot be carried out for Latgale special economic zone, because authors set limitation that impact of special economic zone was examined by all Latgale region, not every local municipality. Special economic zones have been a popular economic (and regional) development tool for several years, still there is a lack of evidence on zone effectiveness and how to improve existing zone programs (Boranet, 2001).

This paper examines whether different impacts of special economic zones may be detected by looking at unemployment level.

\section{Influence on unemployment level in Latgale region by prognosis of new job places in Latgale special economic zone}

In case of Latgale special economic zone, by creation of regulatory framework in 2016, it was determined that 200 new job places should be created in each two years, starting from 2017. Authors presume that in each two years can be created 200 more new job places, from 2017 till 2022, in total 600 new job places. The first challenge in estimating the effects of special zones is to identify geographic areas that precisely reflect zone boundaries for which outcomes (such as new job places) can be measured (Neumark et al., 2010). In case of Latgale special economic zone authors did not use approach to measure and evaluate new job places in every local municipality of Latgale region because of data limitations. Economists approves that amount of job creation will depend on industry characteristics, as well as special economic zone incentives for employment (Billings, 2009).

According to regulatory framework, creation of new job places is not precondition to qualify for special economic zone company status. The companies of the Latgale Special Economic Zone are entitled to qualify for the direct tax relief and application of indirect taxes in accordance with the procedures laid down in the laws and regulations for the investments which are made. Based on the information from Ministry of Environmental Protection and Regional Development (Latvia), despite to short operating time of Latgale special economic zone (launched on January 2, 2017), till August, 2017 six investment projects are approved with private investment 1052962 euro and 35 new job places in total. Investment project is main precondition for enterprise to qualify for special economic zone status.

In assessing the impact of special economic zones, it is desirable to determine the impact of contribution on the socio-economic development of territories, not only capture the fact that some specific indicators are reached. In case of Latgale special economic zone contribution can be analysed by prognosis of new job places which will be created in 2022 and evaluation of potential reduction of unemployment level in Latgale region. (Authors use year 2022 as reference year because of forecasts of the Ministry of Economics (Latvia).)

Authors have developed custom case model how to assess influence from prognosis about new job places on unemployment level in Latgale region (see step-by-step model hereafter and calculations in Table 1).

NB! To evaluate influence in Latgale region, calculation till step 7 includes information about other Latvia`s regions. 
Table 1. Influence on unemployment level in Latgale region by prognosis of new job places in Latgale special economic zone

\begin{tabular}{|c|c|c|c|c|c|c|c|c|c|}
\hline & Step 1 & Step 2 & Step 3 & Step 4 & Step 5 & Step 6 & Step 7 & Step 8 & Step 9 \\
\hline Region & $\begin{array}{l}\text { Number of } \\
\text { job seekers } \\
\text { (thousand), } \\
\text { year } 2016\end{array}$ & $\begin{array}{l}\text { Territorial } \\
\text { proportion } \\
\text { of job } \\
\text { seekers }\end{array}$ & $\begin{array}{l}\text { Prognosis } \\
\text { about job } \\
\text { seekers } \\
\text { (thousand), } \\
\text { year 2022 }\end{array}$ & $\begin{array}{l}\text { Economically } \\
\text { active } \\
\text { population } \\
\text { (thousand), } \\
\text { year } 2016\end{array}$ & $\begin{array}{l}\text { Territorial } \\
\text { proportion of } \\
\text { economically } \\
\text { active } \\
\text { population }\end{array}$ & $\begin{array}{l}\text { Prognosis } \\
\text { about } \\
\text { economically } \\
\text { active } \\
\text { population } \\
\text { (thousand), } \\
\text { year } 2022\end{array}$ & 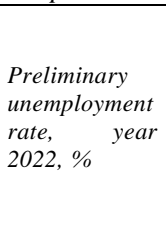 & $\begin{array}{l}\text { Number of } \\
\text { new iob } \\
\text { places in } \\
\text { Latgale } \\
\text { special } \\
\text { economic } \\
\text { zone, year } \\
2022 \quad \text { on }\end{array}$ & $\begin{array}{l}\text { Decrease of } \\
\text { unemployment } \\
\text { level, year } \\
2022 \\
\text { (percentage } \\
\text { points) }\end{array}$ \\
\hline $\begin{array}{l}\text { Riga } \\
\text { region }\end{array}$ & 37,7 & 0,3956 & 24,0 & 524,7 & 0,5308 & 534,68 & 4,48 & $\mathrm{n} / \mathrm{a}$ & $\mathrm{n} / \mathrm{a}$ \\
\hline $\begin{array}{l}\text { Vidzeme } \\
\text { region }\end{array}$ & 8,6 & 0,0902 & 5,5 & 93,4 & 0,0945 & 95,18 & 5,75 & $\mathrm{n} / \mathrm{a}$ & $\mathrm{n} / \mathrm{a}$ \\
\hline $\begin{array}{l}\text { Kurzeme } \\
\text { region }\end{array}$ & 11,8 & 0,1238 & 7,5 & 120,5 & 0,1219 & 122,79 & 6,11 & $\mathrm{n} / \mathrm{a}$ & $\mathrm{n} / \mathrm{a}$ \\
\hline $\begin{array}{l}\text { Zemgale } \\
\text { region }\end{array}$ & 14,1 & 0,1480 & 9,0 & 117,7 & 0,1191 & 119,94 & 7,48 & $\mathrm{n} / \mathrm{a}$ & $\mathrm{n} / \mathrm{a}$ \\
\hline $\begin{array}{l}\text { Latgale } \\
\text { region }\end{array}$ & 23,1 & 0,2424 & 14,7 & 132,4 & 0,1339 & 134,92 & 10,89 & 600 & $-0,44$ \\
\hline LATVIA & 95,3 & 1 & 60,6 & 988,6 & 1 & 1007,4 & 6,02 & $\mathrm{n} / \mathrm{a}$ & $\mathrm{n} / \mathrm{a}$ \\
\hline
\end{tabular}

Source: authors' designed

Step 1. Based on data from Central Statistical Bureau of Latvia, division of population by labour status "job seekers" (age group 15-74 years) in year 2016 according to Latvia`s statistical regions is given. Job seekers in Latgale region in year 2016 was 23,1 thousand.

Step 2. Using the data from Step 1, the territorial proportion of job seekers is calculated. From total number of job seekers in Latvia, 24, 24\% are in Latgale region.

Step 3. According to the forecasts of the Ministry of Economics (Latvia), in year 2022 there will be 60, 6 thousand job seekers in Latvia. Based on authors assumption and territorial proportion of job seekers in year 2016, calculation about prognosed job seekers in year 2022 according to Latvia`s statistical regions is calculated. From total number of job seekers in year 2022 in Latgale region will be 14, 7 thousand.

Step 4. Based on data from Central Statistical Bureau of Latvia, division of population by status "economically active population" (age group 15-74 years) in year 2016 according to Latvia`s statistical regions is given. Economically active population in Latgale region in year 2016 was 132, 4 thousand.

$\underline{\text { Step } 5}$. Using data from Step 4, the territorial proportion of economically active population is calculated. From total number of economically active population in Latvia, 13, 39\% are in Latgale region.

Step 6. According to the forecasts of the Ministry of Economics (Latvia), in year 2022 there will be 1007, 4 thousand economically active population in Latvia. Based on authors assumption and territorial proportion of economically active population in year 2016, calculation about potential economically active population in year 2022 according to Latvia`s statistical regions is calculated. From total number of economically active population in year 2022 in Latgale region will be 10, 89 thousand.

Step 7. According to the prognosis of job seekers and economically active population in the regions, authors calculated the preliminary unemployment rate in each region in year 2022; the number of job seeker prognosis was assigned to the number of economically active population prognosis.

Step 8 . As mentioned before, authors presume that each two years can be created 200 new job places in Latgale special economic zone; from 2017 till 2022, in total 600 new job places. calculated.

Step 9. Based on authors' custom case model, potential decrease of unemployment in Latgale region, was

Some economists declare that evidence indicates that enterprise zones do not increase employment (Kolko, 2010), at the same time this paper shows opposite evidence. Influence from provisional new job places in Latgale special economic zone till year 2022, unemployment level will be decreased by 0,44 percentage points. This confirms that special economic zones are significant regional development instrument for promotion of entrepreneurship in territories with unfavourable socio-economic situation.

\section{CONCLUSIONS}

1. Regional policy planners in national level and local level use multiform instruments for promotion of entrepreneurship in territories with unfavorable socio-economic situation, mainly instruments can be used without specific normative regulation in national level, but in some cases as local tax and fees relief, specific normative regulation in national level has to be established.

2. By changing paradigms of regional policy nowadays and instruments used to promote entrepreneurship in regions, the case of Latvia highlights establishment of Latgale special economic zone as significant example for regional development instrument which is used for one single region individual according to its socio-economic situation. Regarding to European Union national framework, special economic zones should be an integral part of national reginal policy guidelines to achieve relevant impact on territories. 
3. Authors concludes that influence from provisional new job places in Latgale special economic zone till year 2022 , unemployment level will decrease by 0,44 percentage points. This confirms that special economic zones are significant instrument for promotion of entrepreneurship in territories with unfavourable socio-economic situation.

\section{ACKNOWLEDGMENTS}

The paper was supported by the National Research Program 5.2. "Economic Transformation, Smart Growth, Governance and Legal Framework for the State and Society for Sustainable Development - a New Approach to the Creation of a Sustainable Learning Community (EKOSOC-LV)". The project No. 5.2.2. "The Development of Innovation and Entrepreneurship in Latvia in Compliance with the Smart Specialization Strategy".

\section{REFERENCES}

1. Apostolache, A. 2014. Regional Development in Romania - From Regulations to Practice. Procedia Economics and Finance, Vol. 8, pp. 35-41. https://doi.org/10.1016/S2212-5671(14)00059-8

2. Barca, F., McCann, P., Rodríguez-Pose, A. 2012. The case for regional development intervention: place-based versus place-neutral approaches. Journal of Regional Science, Vol. 52, pp. 134-152. https://doi.org/10.1111/j.1467-9787.2011.00756.x

3. Billings, S. 2009. Do Enterprise Zones Work? An Analysis at the Borders. Public Finance Review, Vol 37, No. 1, pp. 68-93. https://doi.org/10.1177/1091142108321238

4. Boarnet, M. 2001. Enterprise Zones and Job Creation: Linking Evaluation and Practice. Journal - Economic Development Quarterly, Vol. 15, Iss. 3, pp. 242-254.

5. Bondonio, D., Greenbaum, R. 2007. Do local tax incentives affect economic growth? What mean impacts miss in the analysis of enterprise zone policies. Regional Science and Urban Economics, Vol. 37, pp. $121-136$. https://doi.org/10.1016/j.regsciurbeco.2006.08.002

6. Ciżkowicz, P., Ciżkowicz-Pękała, M., Pękała, P., Rzońca, A. 2017. The effects of special economic zones on employment and investment: a spatial panel modeling perspective. Journal of Economic Geography, Vol. 17, pp. 571-605.

7. Farole, T., Akinci, G. 2011. Special Economic Zones. Progress, Emerging Challenges and Future Directions. Directions in Development; trade. World Bank. Available at https://openknowledge.worldbank.org/handle/10986/2341 (Accessed on 17/11/2016).

8. Hazakis, K. 2014. The rationale of special economic zones (SEZs): An Institutional approach. Regional Science Policy and Practice, Vol. 6, pp. 85-101. https://doi.org/10.1111/rsp3.12030

9. How can special economic zones catalyze economic development? 2015. Asian Development Bank, Asian Economic Integration Report 2015. Available at https://www.adb.org/sites/default/files/publication/177205/asian-economic-integration-report-2015.pdf (Accessed on 01/10/2017).

10. Internal affairs, OECD. 2011. Available at http://www.economist.com/node/18332880 (Accessed on 10/08/2017).

11. Kolko, J., Neumark, D. 2010. Do some enterprise zones create jobs? Journal of Policy Analysis and Management, Vol. 29(1), pp. 5-38. https://doi.org/10.1002/pam.20477

12. Neumark, D., Kolko, J. 2010. Do enterprise zones create jobs? Evidence from California's enterprise zone program. Journal of Urban Economics, Vol. 68, pp. 1-19. https://doi.org/10.1016/i.jue.2010.01.002

13. Regional Development Policies in OECD Countries, 2010. OECD Publishing, p. 384.

14. Regional Policy Guidelines 2013-2019, Latvia. 2013. Available at http://polsis.mk.gov.lv/documents/4525 (Accessed on 07/09/2017).

15. Ziedina, D., Pelse, M. 2017. Main Characteristics of Economic Zones Types: Latvia's Experience. Economics Science for Rural Development: Rural Development and Entrepreneurship, Bioeconomy, Production and Co-operation in Agriculture, Vol. 44, pp. 212-218. 